\title{
Drinking Water Treatment by Inductively Coupled Plasma System to Remove of Microorganisms in River Water
}

\author{
Reni Desmiarti ${ }^{1,}$, Ariadi Hazmi ${ }^{2}$, Primas Emeraldi ${ }^{2}$, Munas Martynis ${ }^{1}$, Yenni Trianda ${ }^{1}$, and Ulung M. Sutopo ${ }^{1}$ \\ ${ }^{1}$ Chemical Engineering Department, Universitas Bung Hatta, 25147, Padang, Indonesia \\ ${ }^{2}$ Electrical Engineering Department, Andalas University, 25166, Padang, Indonesia
}

\begin{abstract}
Inductively coupled plasma system was used in drinking water treatment system to kill the microorganisms in water such as total coliforms (TC), fecal coliforms (FC) and other coliforms $(\mathrm{OC})$ from river water. The aim of this study was to investigate the effect of flowrate on removal efficiency (RE), death rate, and death yield and energy consumption of bacteria's. The frequency of the system was set at $4.6 \mathrm{MHz}$. The results show that the removal efficiencies and death rate of TC, FC and OC decreased with increasing flowrate. Compared to FC, the first-order reactions of TC and OC were lower in the following order: FC > OC > TC. The death yield of TC and OC significantly increased when the removal efficiency increased. The electromagnetic flux varied from 19.44 to $20.55 \mathrm{~W} / \mathrm{cm}^{2}$ and the energy consumption was $0.26,0.32$, and 0.67 with flow rate at 20,10 and $5 \mathrm{~mL} /$ minute, respectively. These results are very necessary to improve drinking water treatment.
\end{abstract}

\section{Introduction}

Kuranji River is a raw water source for the water treatment plant in Padang City, West Sumatra, Indonesia. In this river people wash, bathe and defecate. These activities cause concentrations of pathogenic bacteria, such as total coliforms and fecal coliforms are very high in water. Pathogenic bacteria such as total coliforms (TC), fecal coliforms (FC) and other coliforms (OC) have been detected in natural waters $[1,2]$. Pathogenic bacteria can also enter the surface water and groundwater. The Indonesian Ministry of Health has reported that pathogenic bacteria cause many human deaths in Indonesia through intestinal illnesses such as typhoid and paratyphoid fever.

In drinking water treatment plants, chlorine compounds are used to kill pathogenic bacteria. This process produces tri halo methanes (THMs) as chlorination byproduct from the chlorine reacting with other natural compounds in the water [3]. In the effluent of drinking water treatment plants, THMs concentrations in the range of $80-228 \mathrm{mg} / \mathrm{L}$ have been detected [3]. THMs are very carcinogenic, even at low concentrations. Besides, THMs can trigger the production of free radicals in humans, causing cell injury, the leading cause of cancer in the world.

Plasma can generate oxidizing species radicals $\left(\mathrm{H}^{\bullet}, \mathrm{O}^{\bullet}\right.$, and $\left.\mathrm{OH}^{\bullet}\right)$ and molecules $\left(\mathrm{H}_{2} \mathrm{O}_{2}, \mathrm{O}_{3}\right)$, electrohydraulic cavitation, shockwaves and ultraviolet light [4]. The removal of pathogenic bacteria has been studied using pulsed high voltage [5], photocatalysis using $\mathrm{TiO}_{2}[6,7,8]$, anda combination of adsorbents with plasma [8]. The removal efficiency (RE) of microorganisms varied from
$50-100 \%$. The RE depends on the amount of bacteria, the flowrate and the current. Compared to using the addition of chlorine, fixed-bed filtration and floating media filter-microfiltration, induction plasma is a new technology for the removal of pathogenic bacteria from water. This technology achieves significantly enhanced disinfection of microorganisms and degradation of organic contaminants due to being environmentally friendly, making no demands on temperature and pressure, reaching higher removal efficiencies, and being unresponsive to pollutants.

In a previous study, the authors have investigated the removal of pathogenic bacteria such as TC, FC and OC using plasma in a batch experiment [9]. The removal of TC and FC was about $93 \%$ and $95 \%$, respectively. The current work concentrated on the use of a plasma electric system to study the effect of flowrate on the treatment of pathogenic bacteria. The aim of this study was to investigate the application of inductively coupled plasma to remove pathogenic bacteria from river water. Based on the experimental data, the removal efficiency and disinfection yield were evaluated.

\section{Material And Methods}

\subsection{Source of Water}

River water was took from Kuranji river. This river is raw water for water treatment plant in Padang city, West Sumatra, Indonesia. The characteristics of river water is shown in Table 1. 
Table 1. The characteristics of Kuranji river

\begin{tabular}{|l|l|r|}
\hline Parameters & Unit & Values \\
\hline Electric Conductivity (EC) & $\mu \mathrm{S} / \mathrm{cm}$ & 150 \\
\hline Total Dissolved Solid (TDS) & $\mathrm{mg} / \mathrm{L}$ & 75 \\
\hline $\mathrm{pH}$ & - & 8.2 \\
\hline Total coliforms & $\mathrm{CFU} / 100 \mathrm{~mL}$ & 25.000 \\
\hline Fecal coliforms & $\mathrm{CFU} / 100 \mathrm{~mL}$ & 5.500 \\
\hline Other coliforms & $\mathrm{CFU} / 100 \mathrm{~mL}$ & 18.000 \\
\hline
\end{tabular}

\subsection{Experiments}

The inductively coupled plasma system involved a radio frequency generator and a plasma reactor, as shown in Fig.1. This system was equipped with a current probe (Tektronix P6022 in USA), a high-voltage probe (Tektronix P6015A in USA), a Picoscope 4424 with four channels, and a glass reactor with a volume of $100 \mathrm{ml}$ wrapped in copper wire $(\varnothing 2 \mathrm{~mm})$. To investigate the effect of flowrate on the removal of TC, FC and OC, the flowrate was controlled at 5,10 and $20 \mathrm{ml} /$ minute using a peristaltic pump. The effluent was checked at 10, 30, 60, 120, 150 minutes. The frequency of the system was set at 4.6 $\mathrm{MHz}$ [9]. The oscilloscope, the high-voltage probe and the current probe were used to record the applied voltages and discharge currents.

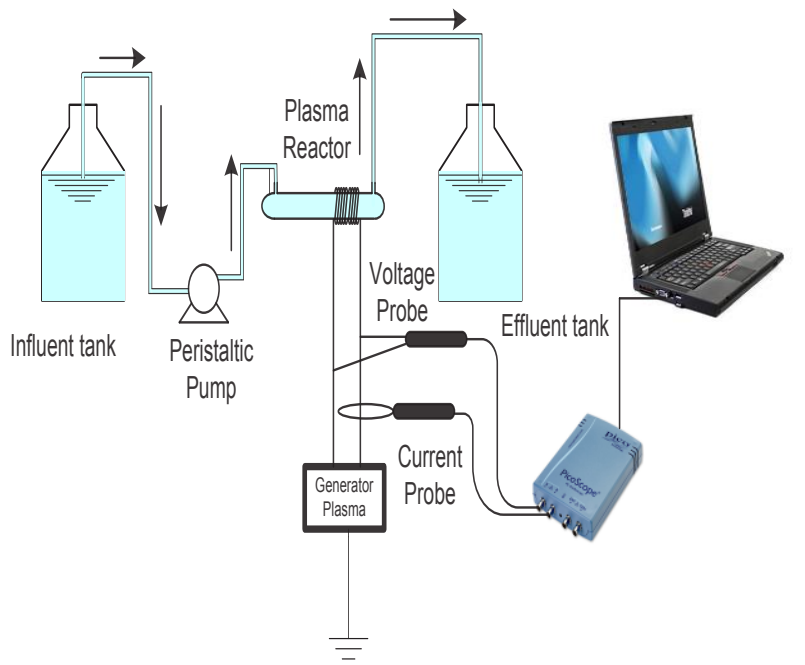

Fig. 1. Experimental set-up of electric plasma system

\subsection{Analysis}

The number of microorganisms was measured with the plate count method $[8,12]$. To give $10^{1}$ dilutions, $0.5 \mathrm{~mL}$ of treated water was added into a tube containing $4.5 \mathrm{~mL}$ of normal saline water. Then, the tube was carefully mixed on a vortex for one minute. Agar plates were prepared by adding $14.05 \mathrm{~g}$ of nutrient agar (brilliant green lactose bile $2 \%$ (BGLB) broth by Oxoid, UK) to $500 \mathrm{~mL}$ of sterilized ultra-pure water.
To analyze the number of pathogenic bacteria, $1 \mathrm{~mL}$ of treated water was poured onto a petri dish with a diameter of $5 \mathrm{~cm}$, containing $5 \mathrm{~mL}$ of melted nutrient agar and then kept at $37{ }^{\circ} \mathrm{C}$ in an incubator for $24 \mathrm{~h}$. The total number of microorganisms was counted by enumerating purple, pink and white colonies formed as fecal coliforms, total coliforms and other coliforms, respectively, in a colony-forming unit (CFU/mL).

\section{Results and Discussion}

\subsection{Death rate of microorganisms}

Fig. 2 illustrates the removal efficiency (RE) of TC, FC, and $\mathrm{OC}$ when the applied frequency was set at $4.6 \mathrm{MHz}$ and the flowrate at 5, 10 and $20 \mathrm{~mL} /$ minute. Fig. 2 shows that the RE of TC, OC and FC in the effluent increased to 44,54 and $73 \%$, respectively after 30 minutes of treatment time, and after running 60 minutes increased to 74, 89 and $100 \%$ with respect to $\mathrm{TC}, \mathrm{OC}$ and $\mathrm{FC}$, respectively. Compared with previous studies using groundwater the removal efficiency of FC and TC were lower $[8,9]$. Similar results were also found with the flow rate at 10 and $20 \mathrm{~mL} /$ minute (Fig. $2 \mathrm{~b}$ and $2 \mathrm{c}$ ). This is due to the high concentration of microorganisms in the river compared to groundwater. In another study, using a combination of floating media filter-microfiltration and coagulation, Chiemchaisri et al. [11] found a RE of FC and TC in the range of $96-98 \%$ and $52-98 \%$, respectively. This hybrid system requires high energy and uses $\mathrm{FeCl}_{3}$ and Alum as coagulants. 

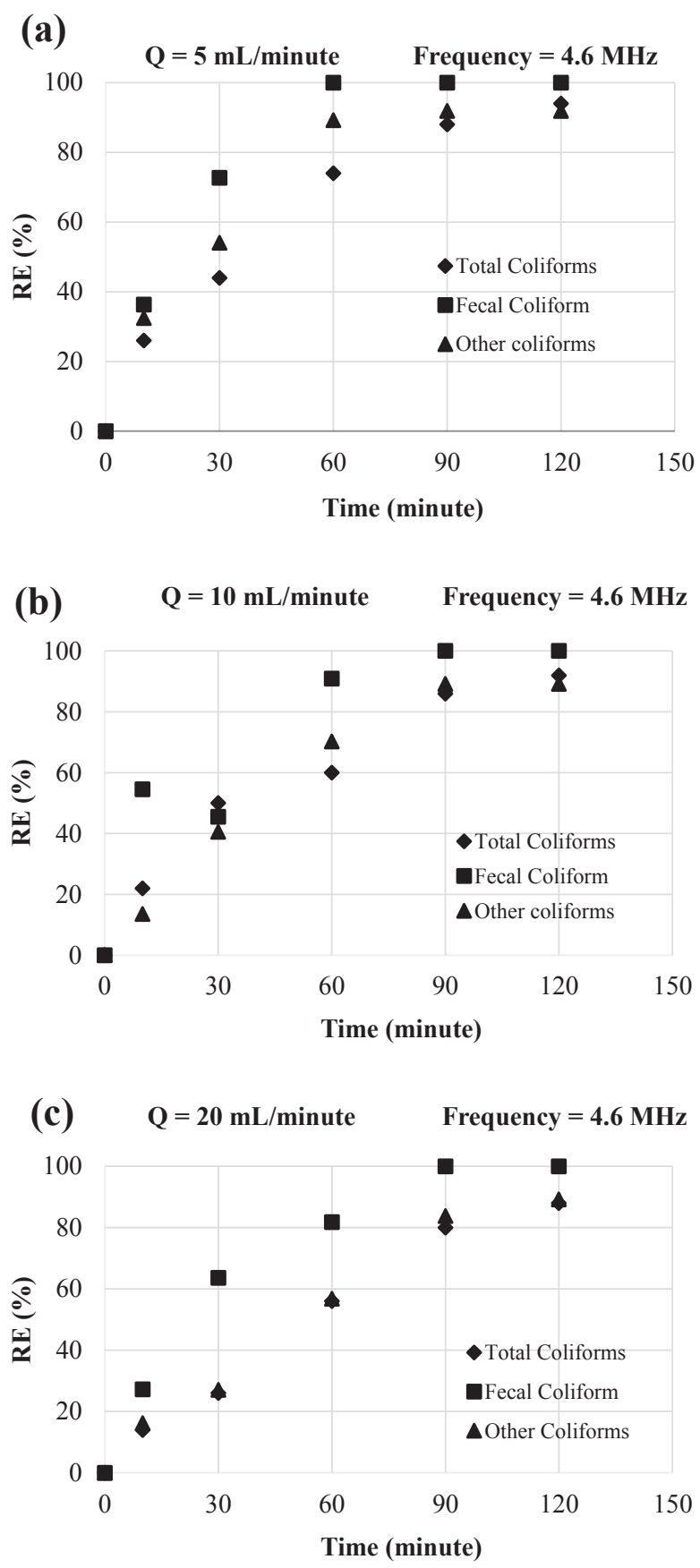

Fig. 2. Profile of pathogenic bacteria during experiment

The death rate kinetic $(k)$ of the pathogenic bacteria was calculated by first-order reaction. $k$ was calculated by plotting $\ln \mathrm{C} / \mathrm{C}_{0}$ vs t. As displayed in Fig.3, the correlation coefficients $\left(\mathrm{R}^{2}\right)$ were $0.85 \sim 0.97$. The $k$ values were calculated from the slopes. The results show that the $k$ values decreased with increasing flowrate, suggesting that the flowrate controls the disinfection of pathogenic bacteria in river water.

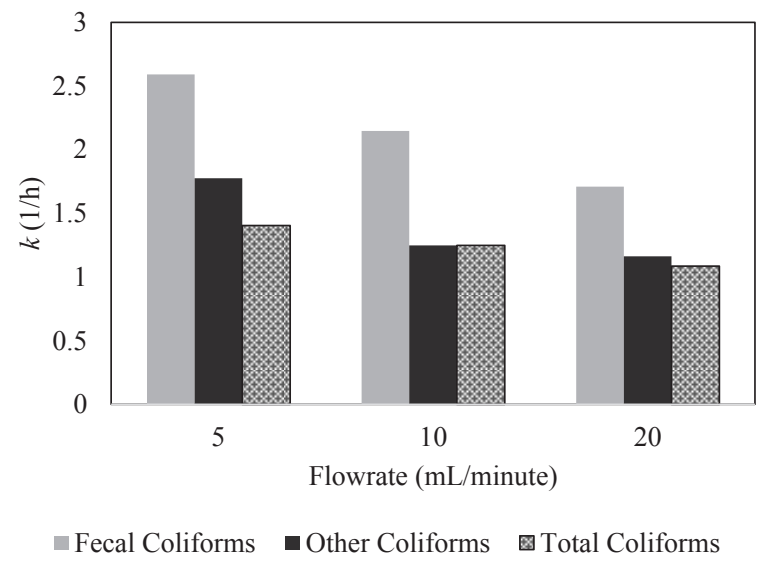

Fig. 3 The death rate of pathogenic bacteria at different flowrates.

\subsection{Death yield}

The death yield is defined as the number of deaths of pathogenic bacteria per unit of energy consumed in the process to describe the removal efficiency $[8,12]$. The death yield of bacteria was calculated using the following Eq. (1):

$$
Y=\frac{N_{0} x V x \frac{1}{100} x R E}{P x t}
$$

where $\mathrm{Y}(\mathrm{CFU} / \mathrm{KWh})$ is death yield $(\mathrm{CFU} / \mathrm{L}), \mathrm{V}(\mathrm{L})$ is volume of water in the reactor, $\mathrm{P}(\mathrm{KW})$ is average power, and $\mathrm{t}(\mathrm{h})$ is retention time.

The death yields (DY) with varied flowrates are shown in Fig. 4a-4c. Generally, the disinfection yields of FC, TC and OC increased with increasing removal efficiency (RE). The disinfection yield also increased with increasing flowrate. The death yield of TC was higher compared to $\mathrm{FC}$ and $\mathrm{OC}$. In the present study a good correlation was obtained for the effect of flowrate on the death yield of TC, FC and OC.

Our previous study found that the death yield of TC was four times higher than that of FC with inductively coupled plasma in a batch experiment to treat ground water [8]. These results showed that the death yield of bacteria using a plasma system depends on energy consumption, flowrate and type of microorganism. In an inductively coupled plasma system, active species can be generated by decomposition of ozone and peroxide and it can also produce shock waves and ultraviolet light $[4,5,13,14]$. The most important result from the present study is that the flowrate is a key parameter in the removal of all microorganisms from water. Moreover, the results are needed to improve the design drinking water treatment plants in the future. 


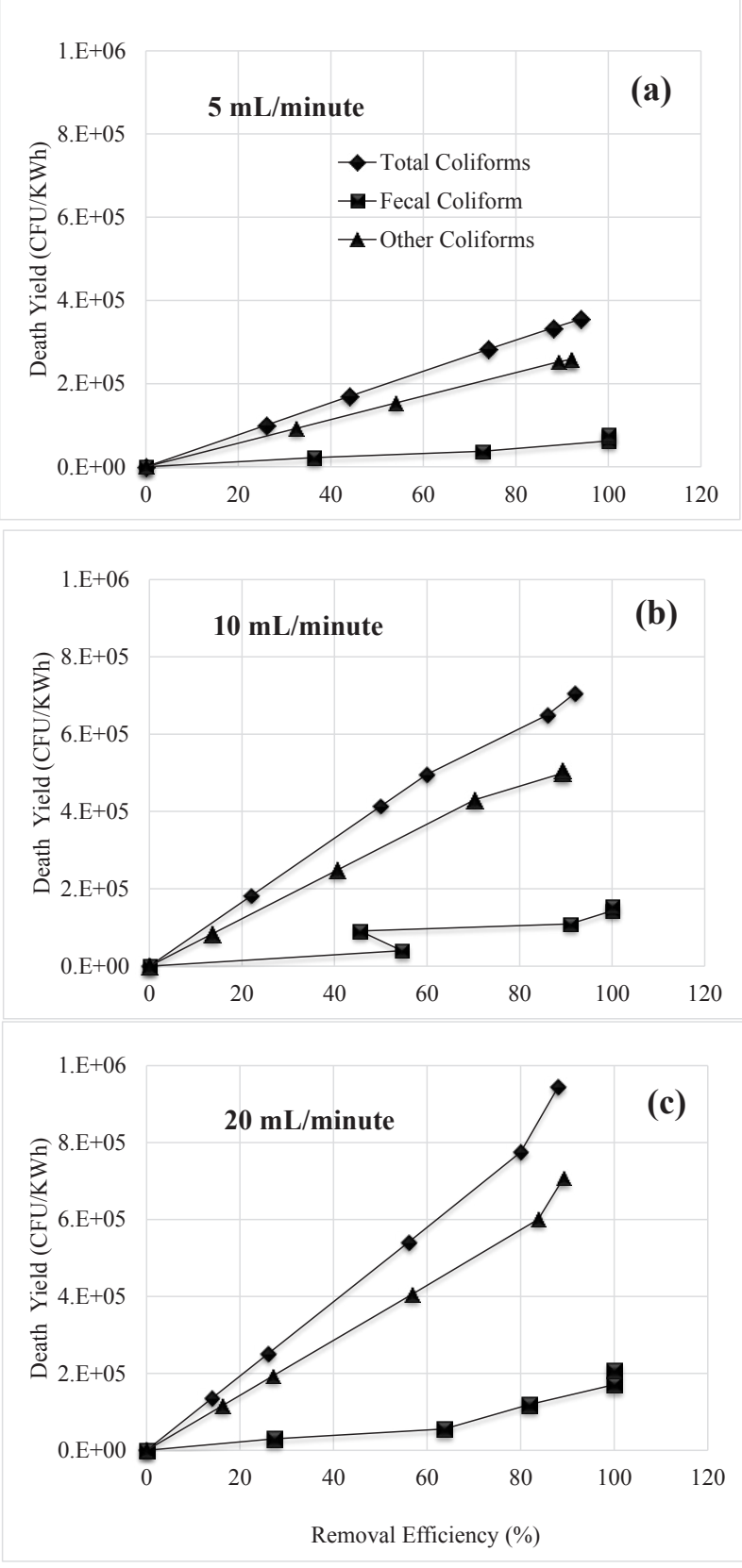

Fig. 4. Relationship between removal efficiency and death yield of pathogenic bacteria.

\subsection{Electromagnetic Flux (S) and Energy Consumption (Econs.)}

The performance of the inductively coupled plasma system was confirmed using electromagnetic flux $(S)$ and calculated using Eq. (2) $[6,13]$.

$$
S=9.94 \cdot 10^{-2} \cdot(I . n)^{2} \sqrt{\frac{f}{\sigma}}
$$

where $\mathrm{S}$ is electromagnetic flux $\left(\mathrm{W} / \mathrm{cm}^{2}\right)$, I is current (A), $\mathrm{n}$ is number of turns per unit length (turn/ $\mathrm{cm}$ ), $\mathrm{f}$ is frequency $(\mathrm{MHz})$, and $\sigma$ is electric conductivity $\left(\mathrm{ohm}^{-1}\right.$ $\left.\mathrm{cm}^{-1}\right)$. The electromagnetic flux generated in the inductively coupled plasma reactor was quite similar in all runs, from $19.44 \pm 1.63$ to $20.55 \pm 0.23 \mathrm{~W} / \mathrm{cm}^{2}$. The energy consumption was calculated at $0.67,0.32,0.26$ $\mathrm{KWh} / \mathrm{L}$ with flowrate at 5,10 and $20 \mathrm{~mL} /$ minute, respectively. These results were achieved with a quite stable current during the experiments.

\section{Conclusion}

An inductively coupled plasma system was used to remove total coliforms (TC), fecal coliforms (FC) and other coliforms (OC) from river water. The removal efficiency of TC, FC and OC decreased with increasing flowrate. The removal efficiency of TC and OC in all runs was lower than that of FC. The death yields of pathogenic bacteria increased significantly when removal efficiency increased. During the experiments, the electromagnetic flux was quite similar, from $19.44 \pm 1.63$ to $20.55 \pm 0.23$ $\mathrm{W} / \mathrm{cm}^{2}$. To remove all pathogenic bacteria in river water, further research is needed to combine plasma system with others processes such as filtration.

This work was supported by Ministry of Research, Technology and Higher Education, Republic of Indonesia (RISTEK DIKTI) in accordance with the Contract of Research Number : 001/KONTRAK-PENELITIAN/K10/ KM/2017 dated April $10^{\text {th }}, 2017$.

\section{References}

1. G. Wilkes, T. Edge, V. Gannon, C. Jokinen. Lyautey, E.; Medeiros, D., Water Research, 43, 2209-2223 (2009).

2. C. Levatensi, L. Bonadonna. Briancesco R.; Grohmann E.; Toze S.; Tandoi V., 45, 587-602 (2012).

3. F.B.J. Jackline, S.M. Hiasmyne, C.B. Patricia, J.A. Nelio., International Journal of Food Microbiology, 190, 9-13 (2014).

4. C. Chiemchaisri, S. Passananon, H.H. Ngo, S. Vigneswaran., Desalination, 234, 335-343 (2009).

5. A. Hazmi, R. Desmiarti, E.P. Waldi, D. Darwison., J. Engineering Technological Sciences, 45, 1, 1-8 (2013).

6. M. Khraisheh, L. Wu, A.H. Al-Muhtaseb, M.A. Al-Ghouti., Journal of Industrial and Engineering Chemistry, 28, 369-376 (2015).

7. M. Kharaisheh, J. Kim, L. Campos, H. Al-Muhtaseb, A. Al-Hawari, M. Al Ghouti, G.M. Walker., Journal of Industrial and Engineering Chemistry, 20, 3, 979-987 (2014).

8. S.N. Hussain, A.P. Trzcinski, H.M.A. Asghar, H. Sattar, N.W. Brown, E.P.L. Roberts., Journal of Industrial and Engineering Chemistry, 44, 216-225 (2016)

9. R. Desmiarti, A. Hazmi, S. Ellyta, Y. Trianda., Research Journal of Pharmaceutical, Biological and Chemical Sciences, 6, 1, 889-897 (2015).

10. R. Devi, E. Alemayehu, V. Singh, A. Kumar, E. Mengistie., Bioresource Technology, 99, 2269-2274, (2008). 
11. C. Chiemchaisri, S. Passananon, H.H. Ngo, S. Vigneswaran., Desalination, 234, 335-343 (2009).

12. B. Van den Akker, T. Trinh, H.M. Coleman, R.M. Stuetz, P. Le-Clech., Bioresource Technology, 55, 432-437(2014).

13. M. Magureanu, D. Piroi, N.B. Mandache, V. David, A. Medvedovici, V.I. Parvulescu., Water Research, 44, 3445-3453 (2010).

14. H. Krause, B. Schweiger, J. Schuhmacher, S. Scholl, U. Steinfeld, Chemosphere, 75, 163-168 (2009). 